\title{
Evaluation of the protective effects of icariin on nicotine-induced reproductive toxicity in male mouse -a pilot study
}

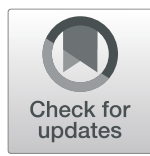

Guochao $\mathrm{Ni}^{1}$, Xuhui Zhang ${ }^{2}$, Seth Yaw Afedo ${ }^{1}$ and Rong Rui ${ }^{*}$

\begin{abstract}
Background: Nicotine, a pharmacologically active component of tobacco adversely affects the male reproductive system and fertility whereas icariin (ICA), the main active ingredient in Epimedium herba has been used in the treatment of several male reproductive problems. This study aimed at evaluating the protective or ameliorative effect of ICA against reproductive toxicity induced by intraperitoneal injection of nicotine in mice.

Methods: Using simple random allocation, forty male mice were randomly divided into 4 groups: control (received $0.35 \mathrm{~mL}$ physiological saline via gastric gavage), nicotine $(0.75 \mathrm{mg} / \mathrm{kg}$ BW/day intraperitoneally), ICA (75 mg/kg BW/ day gastric gavage), and nicotine plus ICA (nicotine, $0.75 \mathrm{mg} / \mathrm{kg}$ BW/day intraperitoneally + ICA, $75 \mathrm{mg} / \mathrm{kg}$ BW/day gastric gavage) group. After 35 days of treatment, the mice were weighed, sacrificed, and their reproductive organs (testis and epididymis) were collected and examined for further studies.

Results: The nicotine-treated group showed significantly decreased epididymal sperm density and serum testosterone concentration relative to the control group. Nicotine also caused oxidative damage shown by significant reduction in the activities of antioxidant enzymes and elevation in Malondialdehyde (MDA) levels. ICA on the other hand, improved the reduction in sperm density, hormone levels, and activities of antioxidant enzymes altered in the nicotine treated mice.
\end{abstract}

Conclusions: These findings indicate that nicotine-induced reproductive toxicity and oxidative damage on male reproductive tissues could be attenuated by ICA.

Keywords: Icariin, Nicotine, Sperm density, Testosterone, Antioxidant enzyme, Male mice

\section{Introduction}

Tobacco contains numerous compounds among which nicotine is the most addictive and toxic component. Among users of tobacco, nicotine plays a significant role in the development of cardiovascular disorders, pulmonary diseases, lung cancer, and many other diseases $[1,2]$. Nicotine has also been known to cause oxidative stress (OS) by inducing the generation of reactive oxygen species (ROS) in tissues [3]. In addition, it adversely affects

\footnotetext{
* Correspondence: rrui@njau.edu.cn

1 Department of Clinical Veterinary Medicine, College of Veterinary Medicine, Nanjing Agricultural University, Nanjing 210095, Jiangsu, China

Full list of author information is available at the end of the article
}

the male reproductive system and fertility [4]. Several studies have also reported that nicotine adversely affects spermatogenesis, epididymal sperm count, motility, and the fertilizing potential of sperms [5-8]. Nicotine causes disturbances in the function of Leydig cells, thus diminishing the production of testosterone [8].

Medicinal plants and their active ingredients have received greater attention as potential anti-peroxidative agents. Icariin (ICA), $\left(\mathrm{C}_{33} \mathrm{H}_{40} \mathrm{O}_{15}\right.$; molecular weight: 676.67), the main active flavonoid glucoside from Epimedium herba is associated with a wide range of pharmacological and biological activities, including anti-inflammatory, antidepressant, anti-tumor activity,

(c) The Author(s). 2020 Open Access This article is licensed under a Creative Commons Attribution 4.0 International License, which permits use, sharing, adaptation, distribution and reproduction in any medium or format, as long as you give appropriate credit to the original author(s) and the source, provide a link to the Creative Commons licence, and indicate if changes were made. The images or other third party material in this article are included in the article's Creative Commons licence, unless indicated otherwise in a credit line to the material. If material is not included in the article's Creative Commons licence and your intended use is not permitted by statutory regulation or exceeds the permitted use, you will need to obtain permission directly from the copyright holder. To view a copy of this licence, visit http://creativecommons.org/licenses/by/4.0/ The Creative Commons Public Domain Dedication waiver (http://creativecommons.org/publicdomain/zero/1.0/) applies to the data made available in this article, unless otherwise stated in a credit line to the data. 
antioxidant effect, estrogenic activity, cardiovascular protection, enhancement of bone healing and neuroprotection, immunoregulation, and improved sexual function [9-12]. Experiment on animals has revealed that ICA improves erectile function when administered to aged male rats [13]. ICA supplementation could also elevate exercise endurance as it provides protective effects on exercise-induced OS $[14,15]$. The testes contain an elaborate array of antioxidant enzymes and free radical scavengers which ensure that its twin spermatogenic and steroidogenic functions are not impacted by OS $[16,17]$.

ICA has testosterone mimetic properties. Testosterone plays a leading role in both morphological development and reproductive function in the testis [18]. There are several separate reports on nicotine (as a cause of fertility problems in males) and ICA (as a factor in enhancing male reproduction and fertility) $[1,4,13,19,20]$, but there are no reports on the effects of ICA on nicotineinduced reproductive toxicity. Therefore, this present study was conducted to evaluate the possible protective effect of ICA against nicotine-mediated reproductive toxicity and OS in mice through assessment of reproductive function and activities of the main antioxidant enzymes.

\section{Materials and methods}

\section{Drugs and chemicals}

Nicotine ditartrate was purchased from Adooq Bioscience Co., Ltd. (Irvine,CA, USA) and ICA from Ze Lang Co., Ltd. (Nanjing, China). The SYBR ${ }^{\circ}$ PrimeScript ${ }^{\circ}$ real time-polymerase chain reaction (RT-PCR) Kit (Perfect Real Time) was purchased from TaKaRa Biotech (Liaoning, China). Superoxide dismutase (SOD), glutathione peroxidase (GPx), and malondialdehyde (MDA) assay kits were obtained from Jiancheng Bioengineering Institute (Nanjing, China), and testosterone ( $\mathrm{T}$ ) Radioimmunoassay (RIA) Kit from Abcam (Cambridge, UK).

\section{Ethical approval}

All procedures and protocols involving animals were in accordance with the Animal Ethics Procedure and Guidelines of the People's Republic of China and the Guide for the Care and Use of Laboratory Animals. All animal procedures were also approved by the Institutional Animal Care and Use Committee (IACUC) of Nanjing Agricultural University with Permit No. 2018CB114306.

\section{Animals and experimental design}

Forty healthy male Kunming mice (8-weeks-old) were purchased from Beijing Vital River Laboratory Animal Technology Co., Ltd. (permit number SCXK-Jing 20160011). The mice were purchased 1 week prior to the study, and for the purposes of acclimatization, all mice were routinely raised in a clean area with normal room temperature and fed with standard mouse feed and ordinary water ad libitum. A sample size calculation was made according to Daniel (1999) [21]. The minimum sample was calculated based on the formula: $n=Z^{2} P(1$ P) $/ d^{2}$, where $n=$ sample size, $Z=Z$-score, $P=$ margin of error, and $\mathrm{d}=$ standard deviation. The Z-score is a constant value automatically set based on the decided confidence level. Accordingly, the necessary sample from an unknown population was determined as 385 (95\% confidence level, $50 \%$ standard deviation, and a 5\% margin of error). However, it was not possible to treat or handle tissue samples from 385 mice in 1 day. Therefore, we conducted a pilot study with 40 mice divided into 4 treatment groups as previously suggested by Zhou et al. (2006) [22].

A simple random allocation was used to assign 10 mice to each group. Briefly, each mouse had equal chance to be selected as part of any of the groups to avoid statistical bias. All mice were marked on the ear; from 1 to 40 and paper cards bearing marks of numbers from 1 to 40 were also designed. Using a random number table, the mice were randomly picked and assigned (allocated) to any of the 4 groups under consideration until each group had a total of 10 mice. Group I served as the control, mice assigned to this group were administered $0.35 \mathrm{~mL}$ physiological saline via gastric gavage. Group II mice received intraperitoneal injection of nicotine tartrate (dissolved in $0.9 \%$ physiological saline) at $0.75 \mathrm{mg} / \mathrm{kg} \mathrm{BW} /$ day. The mice assigned to group III

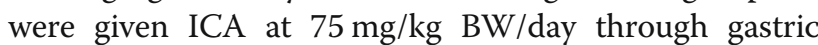
gavage, and finally, group IV mice received intraperitoneal injection of nicotine tartrate (dissolved in $0.9 \%$ physiological saline) at $0.75 \mathrm{mg} / \mathrm{kg} \mathrm{BW} /$ day and then administered ICA at $75 \mathrm{mg} / \mathrm{kg} \mathrm{BW/day} \mathrm{via} \mathrm{gastric} \mathrm{gavage.}$

Each mouse was administered once a day for 35 consecutive days. The dosage of nicotine corresponded to the daily nicotine intake in people who smoke 10-20 cigarette sticks per day $[8,23]$. The mice were weighed weekly to adjust the gavage or injection volume.

\section{Dissection of testes and epididymides}

At the end of treatment, the mice were sacrificed by cervical dislocation. The testes and epididymides were quickly collected and weighed. Testes samples for histopathological examination were kept in Bouin's fixative to preserve normal morphology and facilitate further processing into paraffin blocks. Testes samples collected for assays of biochemical analysis and real-time PCR were snap-frozen in liquid nitrogen and stored at $-80^{\circ} \mathrm{C}$ until they were used for further experiments. The epididymides were used for sperm density analysis. The organ (testicular / epididymal) index was determined as follows: 
Organ (testicular/epididymal) index $=$ organ weight/body weight $\times 1,000$.

\section{Epididymal sperm density}

The left epididymis was used for sperm counting. The epididymides were cut into small pieces after which epididymal spermatozoa were collected and immersed in 4 $\mathrm{mL}$ of human tubal fluid (HTF) in a petri dish $[24,25]$. This was incubated in $5 \% \mathrm{CO}_{2}$ for $15 \mathrm{~min}$ at $37^{\circ} \mathrm{C}$, and homogenization-resistant sperms were counted using haemocytometer. The number of cells in at least 2 of the large corner squares $\left(1 \mathrm{~mm}^{2}\right)$ was counted [26].

\section{Histopathological examination}

The right testis was fixed in Bouin's solution for $24 \mathrm{~h}$ and processed by standard histological procedures. Briefly, specimens were dehydrated in xylene and embedded in paraffin wax, $5 \mu \mathrm{m}$ thick slices were cut from each sample onto a glass slide, and stained with haematoxylin-eosin (HE) routinely. Testicular morphology and structure were observed under the microscope.

\section{Measurement of serum testosterone}

When treatment ended, mice were placed in a plastic air-tight container, together with ketamine $(100 \mathrm{mg} / \mathrm{kg})$ and xylazine $(10 \mathrm{mg} / \mathrm{kg})$ soaked tissue paper and covered immediately for deep anesthesia, after which blood samples were obtained by cardiac puncture. The collected blood samples were centrifuged at $2000 \times \mathrm{g}$ for $10 \mathrm{~min}$ to separate the serum. The serum was stored at $-20^{\circ} \mathrm{C}$ until they were used for further analysis. The serum testosterone concentrations were measured using a radioimmunoassay (RIA) kits.

\section{Determination of SOD, GPx activity, and MDA level}

The testicular tissues stored at $-80^{\circ} \mathrm{C}$ were homogenized after adding pre-cooled $0.9 \%$ physiological saline in the ratio of 1:9. When testicular tissues were disrupted, the homogenate was centrifuged at $5000 \mathrm{rpm}$ for $10 \mathrm{~min}$ at $4{ }^{\circ} \mathrm{C}$. The supernatant was used for assays involving superoxide dismutase (SOD), glutathione peroxidase (GPx), and MDA according to manufacturer's instructions.

\section{Quantitative real-time PCR analysis}

The expression levels of $3 \beta$-hydroxysteroid dehydrogenase $(3 \beta$-HSD), $17 \beta$-hydroxysteroid dehydrogenase $(17 \beta$ HSD), steroidogenic acute regulatory protein (StAR), cytoplasmic superoxide dismutase 1 (SOD1), mitochondrial superoxide dismutase 2 (SOD2), extracellular superoxide dismutase 3 (SOD3), and glutathione peroxidase 1 (GPx1) mRNA in testicular tissues were assessed by qRTPCR. Primers (Table 1) were synthesized at Shanghai Invitrogen Biotech Co. Ltd. Total RNA was extracted from testicular tissues using Trizol reagent (Invitrogen, CA, USA), and according to manufacturer's instructions. The quality and quantity of the RNA preps were determined by gel electrophoresis and Nanodrop ND-1000 spectrophotometer (Nanodrop Technologies Inc., DE, USA). Each real-time PCR reaction was carried out in triplicate in a $20-\mu \mathrm{L}$ reaction mixture $\left(2 \mu \mathrm{L} c \mathrm{cDNA}, 6.8 \mu \mathrm{L} \mathrm{H} \mathrm{H}_{2} \mathrm{O}\right.$, $10 \mu \mathrm{L} \mathrm{SYBR}{ }^{\circ}$ Premix Ex Taq ${ }^{\text {tax }}$, and $0.6 \mu \mathrm{L}$ of each $10 \mu \mathrm{M}$ forward and reverse primers). The PCR program was $30 \mathrm{~s}$ at $95^{\circ} \mathrm{C}$ followed by 40 cycles of $5 \mathrm{~s}$ at $95^{\circ} \mathrm{C}, 31 \mathrm{~s}$ at $60^{\circ} \mathrm{C}$. A melting curve was generated at the end of every run to ensure product uniformity $\left(95^{\circ} \mathrm{C}\right.$ for $15 \mathrm{~s}, 60^{\circ} \mathrm{C}$ for $15 \mathrm{~s}$, $95^{\circ} \mathrm{C}$ for $\left.15 \mathrm{~s}\right)$. The relative expression of target genes was calculated using $2^{-\Delta \Delta \mathrm{Ct}}$ method with $\beta$-actin as an internal control.

\section{Statistical analysis}

The results were expressed as mean \pm standard deviation (SD) of the mean and statistically analyzed by one-way analysis of variance (ANOVA) using SPSS Statistics Package 25 (Chicago, IL, USA) and differences between experimental groups were considered significant at $P<$ 0.05 .

\section{Results}

Effects of icariin and nicotine on body weight, testicular, and epididymal weight

Comparisons of the body weights, testicular and epididymal weights, and testicular and epididymal indices between the four study groups of mice are shown in Table 2 .

\section{Effects of icariin and nicotine on testicle morphology}

Figure 1 shows representative photomicrograph of the testes from the different groups. The seminiferous tubule basement membrane was continuous and complete, and the germ cells had normal morphology and regular arrangement in all groups (Fig. 1a, b, c, and d). Primary spermatocytes and early spermatids were also observed in the control, ICA, and nicotine plus ICA treated groups. However, developed lumina in the seminiferous tubules from the control (Fig. 1a) and ICA (Fig. 1c) treated mice showed complete spermatogenesis and high sperm density compared with that in the nicotine treated mice (Fig. 1b) where low sperm density was observed in constricted lumina. Upon co-treatment with ICA, the lumina of the seminiferous tubules showed complete spermatogenesis and improved sperm density (Fig. 1d).

\section{Effects of icariin and nicotine on epididymal sperm density,serum testosterone concentration, MDA levels, activities of SOD, and GPX in mice testes}

Comparisons of epididymal sperm densities, serum testosterone levels, and testicular tissue OS indices between the four study groups of mice are shown in Table 3. 
Table 1 Primer sequences used in real-time polymerase chain reaction (RT-PCR)

\begin{tabular}{|c|c|c|c|}
\hline Genes & Forward primer & Reverse primer & Lengths of amplicons (bp) \\
\hline$\beta$-actin & TACTGAGCTGCGTITTACACC & TCCTGAGTCAAAAGCGCCAA & 177 \\
\hline $3 \beta-H S D$ & AGATAATCCTGAATGGCAACGA & TTTGCCCGTACAACCGAGA & 245 \\
\hline $17 \beta-H S D$ & TGGGTGCTGTGTTGGATGTG & TGGCACAGTACACTTCGTGG & 153 \\
\hline StAR & TGCGCTTAAATCTCCTAGCTC & TGGCTATCCTTCTGTGTAGACC & 195 \\
\hline SOD1 & AAGCGGTGAACCAGTTGTGT & CCGGGCCACCATGTTTCTTA & 152 \\
\hline SOD2 & AGGAGAGTTGCTGGAGGCTA & TAGTAAGCGTGCTCCCACAC & 228 \\
\hline SOD3 & GAGAAGATAGGCGACACGCA & GAGAACCAAGCCGGTGATCT & 156 \\
\hline GPX1 & ACAGTCCACCGTGTATGCC & CGTTCATCTCGGTGTAGTCCC & 146 \\
\hline
\end{tabular}

$\beta$-actin, Beta-actin; 33-HSD, 3Beta-Hydroxysteroid dehydrogenase; $17 \beta-H S D$, 17Beta-Hydroxysteroid dehydrogenase; StAR, steroidogenic acute regulatory protein; SOD1, cytoplasmic superoxide dismutase 1; SOD2, mitochondrial superoxide dismutase 2; SOD3, extracellular superoxide dismutase 3; GPx1, Glutathione peroxidase 1

Effects of icariin and nicotine on mRNA expression levels of steroidogenic and antioxidant genes in mice testis Comparisons of mRNA expression levels of steroidogenic and antioxidant genes in mice testis between the four study groups of mice are shown in Figs. 2 and 3.

\section{Discussion}

This pilot study evaluated the protective effects of ICA on reproductive toxicity induced by intraperitoneal injection of nicotine in adult male mice. Thirty-five consecutive days of nicotine treatment caused reproductive toxicity; as a result of decreased sperm concentration in the epididymis and increased MDA levels in the testis; however, cotreatment with ICA reversed these trends. This is probably because ICA improved testosterone concentration in blood and antioxidant enzyme activities in the testis thereby ameliorating the adverse effect of nicotine.

The result of our study also demonstrated that nicotine and ICA administration had no significant effect on body weight and epididymal weight/index. In 2014, Chen et al. reported that body weight of rats treated with ICA did not change significantly in any group, suggesting ICA has no obvious effects on adult rat growth [13]. Other studies also reported same findings and our results from ICA treatment were in concordant [10, 27]. On the other hand, Seema (2007) and Hasanzadeh (2017) reported that exposure to nicotine decreased body weight significantly in rats and mice respectively [2, 11]. Also, Williamson (1991), had earlier intimated that, in humans, cigarette smoking results in weight loss, and the smokers gained weight, when they quit smoking [28]. Our findings on nicotine were not the same and we speculate that these differences in weight results could be due to differences in dosage of nicotine administered, the administration route, duration of experiment, or the age of experimental animals.

Testosterone is essential for sexual differentiation, maintenance of spermatogenesis, and expression of male secondary sex characteristics [29]. Holdcraft (2004) reported that testosterone plays a leading role in both morphological development and reproductive function in the testis [18]. We found marked decreased serum testosterone concentrations and epididymal sperm density in the nicotine treated group. This finding was also in agreement with previous studies $[4,9,10,30]$. However, co-treatment with ICA reversed these trends. Previous studies found that administration of E. brevicornum Maxim for 15 d dramatically increased testosterone levels compared with that in the control group and serum testosterone concentrations of ICA treated-rats significantly increased with increasing dosage $[6,13]$. A report in human studies has revealed that the levels of nicotine detected in serum and semen of smokers showed positive correlation with the dose of smoking exposure [4]. In androgen-producing Leydig cells, nitric oxide/cyclic guanosine mono phosphate (NO/cGMP) signaling pathway participates in the regulation of steroidogenic activity [31]. Phosphodiesterase type 5 inhibitors

Table 2 Effects of icariin and nicotine on body weight, reproductive organ weight and index in the experimental mice

\begin{tabular}{lllllll}
\hline Groups & $\begin{array}{l}\text { Initial Body } \\
\text { Weight(g) }\end{array}$ & $\begin{array}{l}\text { Final Body } \\
\text { Weight(g) }\end{array}$ & $\begin{array}{l}\text { Testicular } \\
\text { weight(g) }\end{array}$ & Testicular index (mg/g) & Epididymal weight(g) & Epididymal index (mg/g) \\
\hline Control & $45.15 \pm 2.20^{\mathrm{a}}$ & $52.04 \pm 4.67^{\mathrm{a}}$ & $0.280 \pm 0.023^{\mathrm{a}}$ & $5.39 \pm 0.30^{\mathrm{a}}$ & $0.106 \pm 0.008^{\mathrm{a}}$ & $2.05 \pm 0.11^{\mathrm{a}}$ \\
Nicotine & $46.03 \pm 2.27^{\mathrm{a}}$ & $53.49 \pm 4.10^{\mathrm{a}}$ & $0.279 \pm 0.019^{\mathrm{a}}$ & $5.22 \pm 0.15^{\mathrm{a}}$ & $0.107 \pm 0.011^{\mathrm{a}}$ & $2.00 \pm 0.14^{\mathrm{a}}$ \\
ICA & $44.60 \pm 3.35^{\mathrm{a}}$ & $50.68 \pm 3.76^{\mathrm{a}}$ & $0.302 \pm 0.023^{\mathrm{b}}$ & $5.97 \pm 0.39^{\mathrm{b}}$ & $0.104 \pm 0.007^{\mathrm{a}}$ & $2.05 \pm 0.13^{\mathrm{a}}$ \\
ICA + Nicotine & $44.13 \pm 2.56^{\mathrm{a}}$ & $52.09 \pm 5.01^{\mathrm{a}}$ & $0.288 \pm 0.021^{\mathrm{ab}}$ & $5.56 \pm 0.45^{\mathrm{ab}}$ & $0.105 \pm 0.008^{\mathrm{a}}$ & $2.02 \pm 0.11^{\mathrm{a}}$ \\
P-value & 0.43 & 0.57 & 0.07 & 0.00 & 0.87 & 0.71 \\
\hline
\end{tabular}

Values are expressed as means \pm S.D.; $(n=10)$. Values not sharing a common superscript differ significantly at $P<0.05$. ICA, Icariin 


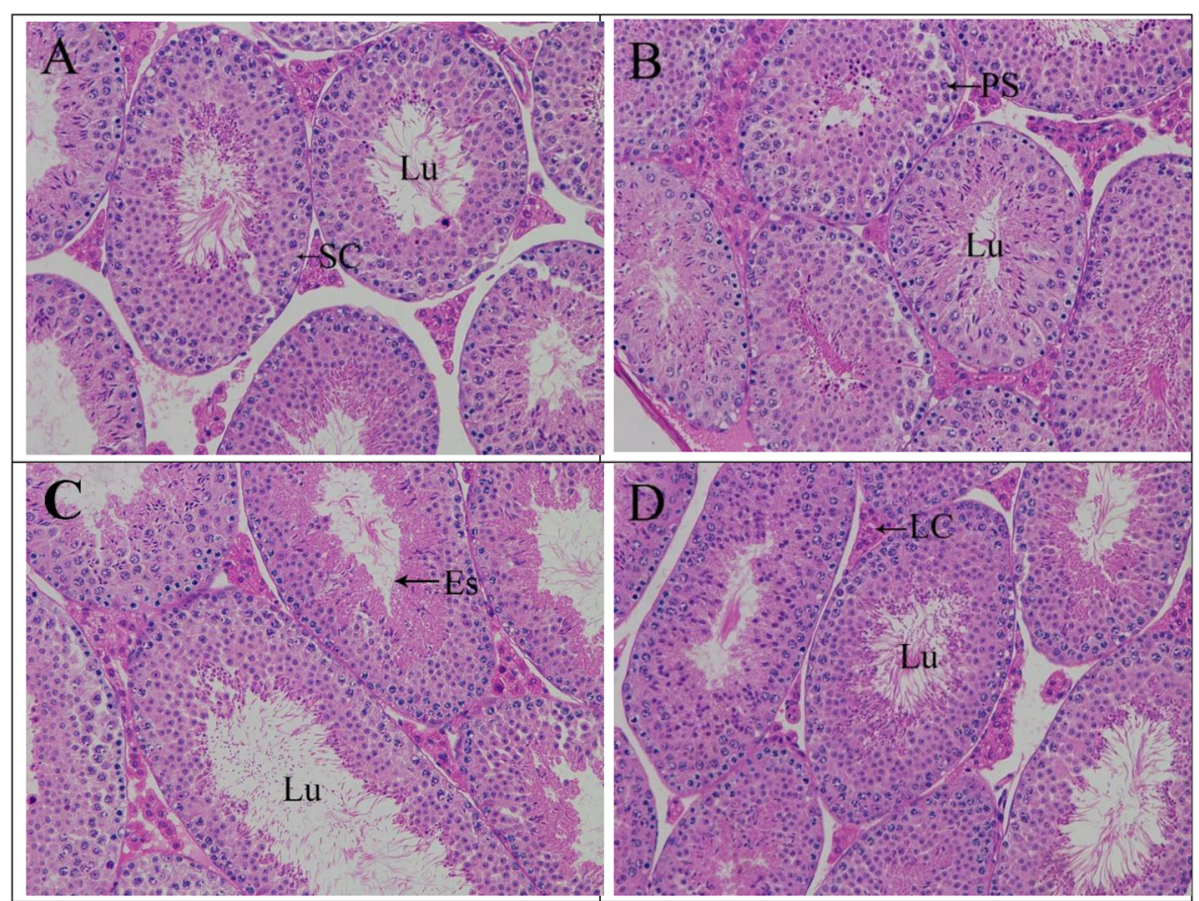

Fig. 1 Haematoxylin and eosin stained sections of testes in different groups $(\times 200)$. a Control, (b) $0.75 \mathrm{mg} / \mathrm{kg}$ BW Nicotine, (c) $75 \mathrm{mg} / \mathrm{kg} \mathrm{BW}$ Icariin, (d) 0.75 mg/kg BW Nicotine plus 75 mg/kg BW Icariin. Lu, lumen; Sc, Sertoli cells; Lc, Leydig cells; PS, primary spermatocyte; ES, early spermatid; BW, body weight

(PDE5-Is) can inhibit PDE5, an enzyme responsible for the degradation of cGMP. Hence PDE5-Is could be involved in the activation of steroidogenic pathways and testosterone secretion. PDE5 is identified in Leydig cells [32]. Zhang et al. in 2012 described ICA as a PDE5-I with the potential to increase cellular cGMP through enhancement of nitric oxide synthase (NOS) in diabetic erectile dysfunction (ED) rats'corpus cavernosum tissue [33]. Considering the effects of ICA on the production of testosterone we speculate that ICA could play an important role in the activation of NO/cGMP pathway. A future study on the mechanism through which ICA improves testosterone production is therefore worth considering.

Testicular $3 \beta-$ HSD and $17 \beta$-HSD plays a pivotal role in the biosynthesis of testosterone, which is a prerequisite for sperm production and maturation [34]. The
mRNA expression level of 3 3 -HSD decreased following nicotine exposure, but the down-regulation tendency reversed as a result of co-treatment with ICA. We also found decreased levels of $17 \beta-$ HSD activity due to nicotine exposure, meanwhile Pant (2003) and Pushpalatha (2005) earlier reported that male reproductive potentials decreased with decreasing testicular 17 $\beta$-HSD activity levels following exposure to several xenobiotics in rats $[35,36]$. Nevertheless, upon ICA treatment the results showed significant increase in $17 \beta$-HSD mRNA expression when compared with the nicotine treated group. StAR as a key transmembrane transport regulator plays a crucial role in testosterone production and its involvement in the transport of cholesterol across mitochondrial membrane is generally considered a rate-limiting step in steroidogenesis. In our study, steroidogenic gene

Table 3 Testicular tissue SOD, GPx activities and MDA level, epididymal sperm density, and serum testosterone levels

\begin{tabular}{llllll}
\hline Groups & SOD (U/mg protein) & GPx (U/mg protein) & MDA (nmol/g protein) & $\begin{array}{l}\text { Epididymal sperm density } \\
\left(10^{7} / \mathrm{mL}\right)\end{array}$ & Testosterone (ng/mL) \\
\hline Control & $159.35 \pm 8.15^{\mathrm{a}}$ & $23.26 \pm 2.72^{\mathrm{a}}$ & $3.97 \pm 0.45^{\mathrm{a}}$ & $1.02 \pm 0.09^{\mathrm{a}}$ & $0.341 \pm 0.057^{\mathrm{a}}$ \\
Nicotine & $147.34 \pm 7.38^{\mathrm{b}}$ & $22.83 \pm 1.46^{\mathrm{ac}}$ & $4.63 \pm 0.67^{\mathrm{b}}$ & $0.83 \pm 0.07^{\mathrm{b}}$ & $0.273 \pm 0.035^{\mathrm{b}}$ \\
ICA & $175.79 \pm 9.03^{\mathrm{c}}$ & $26.74 \pm 1.95^{\mathrm{b}}$ & $3.23 \pm 0.61^{\mathrm{c}}$ & $1.55 \pm 0.31^{\mathrm{c}}$ & $0.675 \pm 0.105^{\mathrm{c}}$ \\
ICA+ Nicotine & $169.55 \pm 4.19^{\mathrm{c}}$ & $24.13 \pm 3.12^{\mathrm{ab}}$ & $3.82 \pm 0.57^{\mathrm{a}}$ & $1.25 \pm 0.19^{\mathrm{c}}$ & $0.494 \pm 0.065^{\mathrm{d}}$ \\
P-value & 0.00 & 0.01 & 0.00 & 0.00 & 0.00 \\
\hline
\end{tabular}

SOD superoxide dismutase; GPx glutathione peroxidase; MDA malondialdehyde; ICA Icariin. All data was expressed in mean $\pm S D ;(n=10) ;$ Values not sharing a common superscript differ significantly at $P<0.05$ 


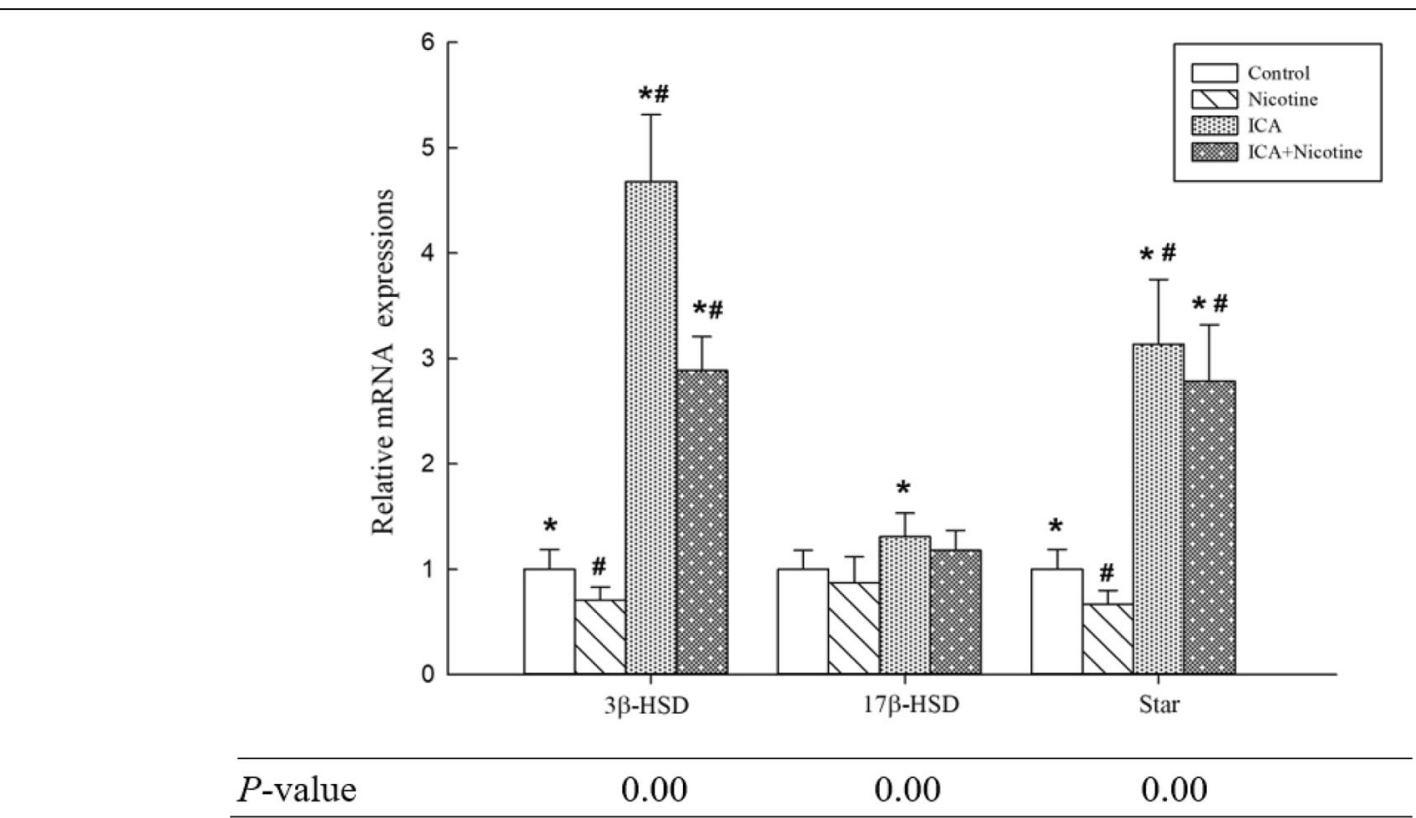

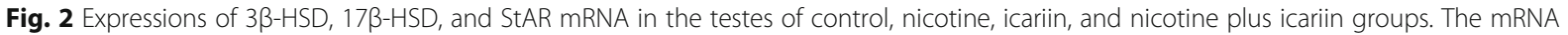
levels were normalized using $\beta$-actin mRNA as internal control. The mRNA levels of the control group were set as 1 . \#P<0.05 compared with the

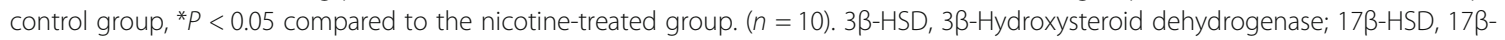
Hydroxysteroid dehydrogenase; StAR, steroidogenic acute regulatory protein

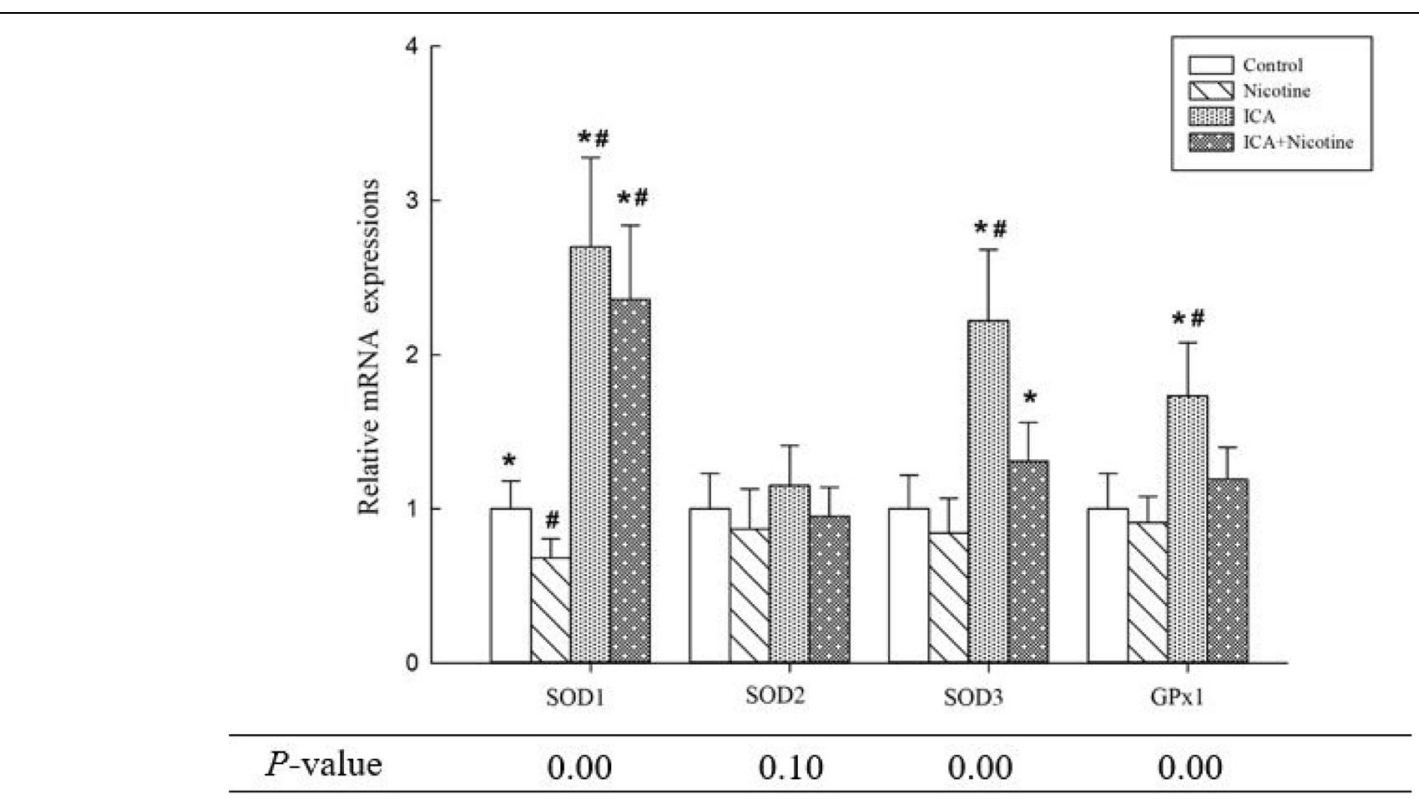

Fig. 3 Expressions of SOD1, SOD2, SOD3, and GPX1 mRNA in the testes of control, nicotine, icariin, and nicotine plus icariin groups. The mRNA levels were normalized using $\beta$-actin mRNA as internal control. The mRNA levels of the control group were set as 1 . \#P<0.05 compared to the control group, ${ }^{*} P<0.05$ compared to the nicotine-treated group. $(n=10)$. SOD1, cytoplasmic superoxide dismutase 1 ; SOD2, mitochondrial superoxide dismutase 2; SOD3, extracellular superoxide dismutase 3; GPx1, Glutathione peroxidase 1 
StAR mRNA expression levels decreased following nicotine exposure, but the down-regulation trend reversed, when the adult mice were co-treated with ICA. The production of testosterone therefore could be affected when the mRNA expression levels of $3 \beta-\mathrm{HSD}, 17 \beta-\mathrm{HSD}$, and StAR are up and down-regulated [13, 37]. This study suggests a possible mechanism through which ICA improves testosterone production.

ROS include hydroxyl radicals $(\cdot \mathrm{OH})$, superoxide anion $\left(\cdot \mathrm{O}_{2}-\right)$, hydrogen peroxide $\left(\mathrm{H}_{2} \mathrm{O}_{2}\right)$, and nitric oxide (NO). ROS overproduction depletes sperm antioxidant system, which leads to a condition of OS. The OS arises when excess free radicals overwhelm the antioxidant defense of the male reproductive tract thereby damaging cells, tissues, and organs $[38,39]$. There exist an elaborate array of antioxidant enzymes and free radical scavengers in the testes, and they ensure that the twin spermatogenic and steroidogenic functions are not impacted by OS $[16,17]$. In cells, the SOD enzyme rapidly converts superoxide anion $\left(\cdot \mathrm{O}_{2^{-}}\right)$to less dangerous hydrogen peroxide $\left(\mathrm{H}_{2} \mathrm{O}_{2}\right)$ so that GPx can decompose $\mathrm{H}_{2} \mathrm{O}_{2}$ to water $[40,41]$. The MDA level is frequently used as key indicative index of tissue OS, which results from free radical damage to membrane components of cells [42]. In our study, administration of nicotine caused decreased activities of SOD and GPx enzymes, while MDA levels in the testes increased, leading to testicular OS. These results are in agreement with previous studies [23, 24]. However, co-treatment with ICA significantly inhibited depletion of SOD enzyme activity (as a result of nicotine exposure) and elevated MDA level in the testes. Testicular OS caused by nicotine was therefore eliminated by co-treatment with ICA. The results of this study suggest a possible protective mechanism of ICA against nicotine-mediated reproductive toxicity.

It is well known that SOD serves as an important antioxidant defense against OS. Three forms of SOD, namely, SOD1, SOD2, and SOD3 are present in mammals. More so, GPx1, the most abundant selenoperoxidase, is a key antioxidant enzyme in various cell types [17, 37]. In our study, the mRNA expression of SOD1 in the testes markedly decreased in the nicotine treated group compared with that in the control group, but when co-treated with ICA, these down-regulation tendencies of SOD1 efficiently reversed. The mRNA expression of SOD3 in the ICA and nicotine plus ICA treated group also increased significantly compared with that in the control and nicotinetreated group. Taniyama in 2003 explained that under physiological conditions, superoxide anions are scavenged by SOD1, SOD2, and SOD3 producing a relatively stable ROS $\mathrm{H}_{2} \mathrm{O}_{2}$ [43]. ICA treatment increased the mRNA expression of GPx1 significantly. Reporting on SOD1, SOD2, SOD3, and GPx1, Yuan et al. (2013) indicated that the mRNA expression of these antioxidant genes in mice testes decreased in the presence of cyclophosphamide (CP) which is a cytotoxic agent [44]. The mRNA expression levels of SOD1 and SOD3 decreased upon nicotine treatment, but co-treatment with ICA reversed these trends, this shows that ICA can protect against cytotoxic agents such as nicotine.

\section{Study limitations}

This pilot study is limited by the low number of mice (sample size) used. A study with much larger sample size will be needed to confirm the protective effect of ICA on nicotine-induced reproductive toxicity in male mouse.

\section{Conclusions}

In conclusion, our results show that nicotine-mediated reproductive toxicity in adult mice was ameliorated through ICA treatment, with characteristic actions such as increase secretion of testosterone, antioxidant capacities, and the suppression of OS. These results suggest that ICA could be used as a potential therapeutic agent in cases of decreased sperm production and OS mediated by cigarette smoking.

\section{Abbreviations \\ ICA: Icariin; BW: Bodyweight; MDA: Malondialdehyde; ROS: Reactive oxygen species; SOD: Superoxide dismutase; GPx1: Glutathione peroxidase 1; OS: Oxidative stress; IACUC: Institutional Animal Care and Use Committee; PCR: Polymerase chain reaction; HTF: Human tubal fluid; HE: Haematoxylin- eosin; RIA: Radioimmunoassay; HSD: Hydroxysteroid dehydrogenase; \\ StAR: Steroidogenic acute regulatory protein; PDE5-Is: Phosphodiesterase type 5 inhibitors; ED: Erectile dysfunction; NOS: Nitric oxide synthase; NO/ CGMP: Nitric oxide / cyclic guanosine mono phosphate; \\ CP: Cyclophosphamide; qRT-PCR: Quantitative real time polymerase chain reaction; SD: Standard deviation; ANOVA: Analysis of variance; SPSS: Statistics Package for Social Sciences}

\section{Acknowledgements \\ Not applicable.}

Authors' contributions

NG and RR designed the study. NG, ZX, and ASY performed most of the experiment and wrote the manuscript. NG and RR contributed to the statistical analysis. NG, ASY, and RR revised the manuscript. All authors read and accepted the manuscript. All authors read and approved the final manuscript.

\section{Funding}

This work was supported by Natural Science Research of Jiangsu Higher Education Institutions of China (CN), China (17KJB230002) and the College of Science and Technology Plan of Jiangsu Polytechnic College of Agriculture and Forestry, China (2018kj16).

\section{Availability of data and materials}

The datasets used and/or analyzed during the current study are available from the corresponding author upon reasonable request.

\section{Ethics approval and consent to participate}

All procedures and protocols involving animals were in accordance with the Animal Ethics Procedure and Guidelines of the People's Republic of China and the Guide for the Care and Use of Laboratory Animals. All animal procedures were also approved by the Institutional Animal Care and Use Committee (IACUC) of Nanjing Agricultural University. There was no human participation in this study.

Consent for publication

Not applicable. 


\section{Competing interests}

The authors declare they have no competing interests.

\section{Author details}

'Department of Clinical Veterinary Medicine, College of Veterinary Medicine Nanjing Agricultural University, Nanjing 210095, Jiangsu, China.

${ }^{2}$ Co-Innovation Center for Sustainable Forestry in Southern China, College of Forestry, Nanjing Forestry University, Nanjing 210037, Jiangsu, China.

Received: 12 December 2019 Accepted: 8 June 2020

Published online: 18 June 2020

\section{References}

1. Mishra A, Chaturvedi P, Datta S, Sinukumar S, Joshi P, Garg A. Harmful effects of nicotine. Indian J Med Paediatr Oncol. 2015;36:24-31.

2. Seema P, Swathy SS, Indira M. Protective effect of selenium on nicotineinduced testicular toxicity in rats. Biol Trace Elem Res. 2007;120:212-8.

3. Kalpana C, Sudheer AR, Rajasekharan KN, Menon VP. Comparative effects of curcumin and its synthetic analogue on tissue lipid peroxidation and antioxidant status during nicotine-induced toxicity. Singap Med J. 2007:48:124-30.

4. Dai JB, Wang ZX, Qiao ZD. The hazardous effects of tobacco smoking on male fertility. Asian J Androl. 2015;17:954-60.

5. Oyeyipo IP, Raji Y, Emikpe BO, Bolarinwa AF. Effects of nicotine on sperm characteristics and fertility profile in adult male rats: a possible role of cessation. J Reprod Infertil. 2011;12:201-7.

6. Mosbah R, Yousef Ml, Mantovani A. Nicotine-induced reproductive toxicity, oxidative damage, histological changes and haematotoxicity in male rats: the protective effects of green tea extract. Exp Toxicol Pathol. 2015;67:253-9.

7. Salahipour MH, Hasanzadeh S, Malekinejad H. Ameliorative effects of Achillea millefolium inflorescences alcoholic extract against nicotineinduced reproductive failure in rat. Exp Toxicol Pathol. 2017:69:504-16.

8. Hasanzadeh KA, Hasanzadeh S, Shalizar JA. Ameliorative effects of Achillea millefolium inflorescences alcoholic extract on nicotine-induced reproductive toxicity in male rat: apoptotic and biochemical evidences. Vet Res Forum. 2017:8:97-104.

9. Pozharitskaya ON, Karlina MV, Shikov AN, Kosman VM, Makarova MN, Makarov VG. Determination of icariin in rat plasma by reverse-phase high-performance liquid chromatography after oral administration of a lipid-based suspension of Epimedium koreanum extract. Biomed Chromatogr. 2008;22:625-9.

10. Pan $Y$, Kong L-D, Li Y-C, Xia X, Kung H-F, Jiang F-X. Icariin from Epimedium brevicornum attenuates chronic mild stress-induced behavioral and neuroendocrinological alterations in male Wistar rats. Pharmacol Biochem Behav. 2007:87:130-40

11. Xin H, Zhou F, Liu T, Li G-Y, Liu J, Gao Z-Z, Bai G-Y, Lu H, Xin Z-C. Icariin ameliorates Streptozotocin-induced diabetic retinopathy in vitro and in vivo. Int J Mol Sci. 2012;13:866-78.

12. Huang Z-S, Xiao H-J, Qi T, Hu Z-M, Li H, Chen D-L, Xu Y-L, Chen J. Antioxidative protective effect of icariin on the FeSO4/H 20 2-damaged human sperm based on confocal raman micro-spectroscopy. J Huazhong Univ Sci Technolog Med Sci. 2014;34:755-60.

13. Chen M, Hao J, Yang Q, Li G. Effects of icariin on reproductive functions in male rats. Molecules. 2014;19:9502-14.

14. QiaoPing C, Ping W. Icariin supplementation protects mice from exerciseinduced oxidant stress in liver. Food Sci Biotechnol. 2013;22:1409-13.

15. Liu T, Xin H, Li W-R, Zhou F, Li G-Y, Gong Y-Q, Gao Z-Z, Qin X-C, Cui W-S, Shindel AW, Xin Z-C. Effects of Icariin on improving erectile function in Streptozotocin-induced diabetic rats. J Sex Med. 2011;8:2761-72.

16. Aitken RJ, Roman SD. Antioxidant systems and oxidative stress in the testes. Mol Mech Spermatogenesis. 2008:636:154-71.

17. Sujatha R, Chitra KC, Latchoumycandane C, Mathur PP. Effect of lindane on testicular antioxidant system and steroidogenic enzymes in adult rats. Asian J Androl. 2001;3:135-8.

18. Holdcraft RW, Braun RE. Hormonal regulation of spermatogenesis. Int J Androl. 2004;27:335-42.

19. Xin ZC. Effects of Icariin on preventive erectile function in diabetic rats and its possible mechanism. J Sex Med. 2010;7:172.

20. Liu T, Xin H, Li WR, Zhang J, Zhou F, Cui WS, Li GY, Gong YQ, Nan Z, Xin ZC. Effects of Icariin on improving erectile function in Streptozotocin-induced diabetic rats. J Sex Med. 2012;9:151.

21. Fahyan SE. Biostatistics : a foundation for analysis in the health sciences / by Wayne W. Daniel: Wiley Sons; 1999.
22. Zhou DX, Qiu SD, Zhang J, Tian H, Wang HX. The protective effect of vitamin $\mathrm{E}$ against oxidative damage caused by formaldehyde in the testes of adult rats. Asian J Androl. 2006;8:584-8.

23. Paunovi MG, Ognjanovi BI, Štajn AŠ, Saičić ZS. Protective effects of quercetin and vitamin $C$ against nicotine-induced toxicity in the blood of Wistar rats. Arh Hig Rada Toksikol. 2016;67:304-10.

24. Yan FH, Chen YF, Zuo ZH, Chen YX, Yang ZM, Wang CG. Effects of tributyltin on epididymal function and sperm maturation in mice. Environ Toxicol Pharmacol. 2009;28:19-24.

25. Goodson SG, Qiu YP, Sutton KA, Xie GX, Jia W, O'Brien DA. Metabolic substrates exhibit differential effects on functional parameters of mouse sperm capacitation Biol Reprod. 2012;87(3):75. https://doi.org/10.1095/biolreprod.112.102673.

26. Oliveira H, Spano M, Santos C, Pereira MD. Lead chloride affects sperm motility and acrosome reaction in mice. Cell Biol Toxicol. 2009;25:341-53.

27. Cheng K, Ge BF, Zhen P, Chen KM, Ma XN, Zhou J, Song P. Ma HP: [effects of icariin and genistein on peak bone mass in rats]. Zhongguo Yi Xue Ke Xue Yuan Xue Bao. 2013;35:542-6.

28. Williamson DF, Madans J, Anda RF, Kleinman JC, Giovino GA, Byers T. Smoking cessation and severity of weight gain in a national cohort. N Engl J Med. 1991 324:739-45.

29. Payne AH, Youngblood GL. Regulation of expression of Steroidogenic enzymes in Leydig-cells. Biol Reprod. 1995:52:217-25.

30. Abd El-Aziz GS, El-Fark MO, Hamdy RM. Protective effect of Eruca sativa seed oil against oral nicotine induced testicular damage in rats. Tissue Cell. 2016;48:340-8.

31. Andric SA, Janjic MM, Stojkov NJ, Kostic TS. Testosterone-induced modulation of nitric oxide-cGMP signaling pathway and androgenesis in the rat Leydig cells. Biol Reprod. 2010;83:434-42.

32. Saraiva KL, Silva AK, Wanderley MI. De Ara"'2jo AA, De Souza JR, Peixoto CA: chronic treatment with sildenafil stimulates Leydig cell and testosterone secretion. Int J Exp Pathol. 2009;90:454-62.

33. Zhang J, Wang YB, Ma CG, Liu T, Li WR, Gong YQ, Xin ZC. Icarisid II, a PDE5 inhibitor from Epimedium wanshanense, increases cellular cGMP by enhancing NOS in diabetic ED rats corpus cavernosum tissue. Andrologia. 2012;44(Suppl 1):87-93.

34. Priya PH, Reddy PS. Effect of restraint stress on lead-induced male reproductive toxicity in rats. J Exp Zool A Ecol Genet Physiol. 2012;317:455-65.

35. Pant N, Srivastava SP. Testicular and spermatotoxic effects of quinalphos in rats. Journal of applied toxicology : JAT. 2003;23:271-4.

36. Pushpalatha T, Srinivas M, Sreenivasula Reddy P. Exposure to high fluoride concentration in drinking water will affect spermatogenesis and steroidogenesis in male albino rats. Biometals. 2005;18:207-12.

37. Das J, Ghosh J, Manna P, Sil PC. Taurine protects rat testes against doxorubicin-induced oxidative stress as well as p53, Fas and caspase 12 mediated apoptosis. Amino Acids. 2012:42:1839-55.

38. Agarwal A, Sekhon LH. The role of antioxidant therapy in the treatment of male infertility. Hum Fertil (Camb). 2010;13:217-25.

39. Martin-Hidalgo D, Bragado MJ, Batista AR, Oliveira PF, Alves MG. Antioxidants and male fertility: from molecular studies to clinical evidence. Antioxidants (Basel). 2019;8(4):89. https://doi.org/10.3390/antiox8040089.

40. Das S, Gautam N, Dey SK, Maiti T, Roy S. Oxidative stress in the brain of nicotine-induced toxicity: protective role of Andrographis paniculata Nees and vitamin E. Appl Physiol Nutr Metab. 2009;34:124-35.

41. Oyeyipo IP, Raji Y, Bolarinwa AF. Antioxidant profile changes in reproductive tissues of rats treated with nicotine. J Hum Reprod Sci. 2014;7:41-6.

42. Hong Z, Hailing L, Hui M, Guijie Z, Leyan Y, Dubing Y. Effect of vitamin E supplement in diet on antioxidant ability of testis in Boer goat. Anim Reprod Sci. 2010;117:90-4.

43. Taniyama Y, Griendling KK. Reactive oxygen species in the vasculature: molecular and cellular mechanisms. Hypertension. 2003;42:1075-81.

44. Yuan D, Wang H, He H, Jia L, He Y, Wang T, Zeng X, Li Y, Li S, Zhang C. Protective effects of total flavonoids from Epimedium on the male mouse reproductive system against cyclophosphamide-induced oxidative injury by up-regulating the expressions of SOD3 and GPX1. Phytother Res. 2014;28:88-97.

\section{Publisher's Note}

Springer Nature remains neutral with regard to jurisdictional claims in published maps and institutional affiliations. 